\title{
Combining acoustic telemetry with a mechanistic model to investigate characteristics unique to successful Atlantic salmon smolt migrants through a standing body of water
}

\author{
Jessie Lilly (D) Hannele M. Honkanen • \\ Joseph M. McCallum • Matthew Newton • \\ David M. Bailey $\cdot$ Colin E. Adams
}

Received: 14 July 2021 / Accepted: 11 October 2021 / Published online: 23 October 2021

(C) The Author(s) 2021

\begin{abstract}
The Atlantic salmon, Salmo salar Linnaeus 1758 , is a charismatic, anadromous species that has faced dramatic declines throughout its range. There is currently a lack of information on the effect of free-standing bodies of water on a key life event, sea migration, for the species. This study extends our understanding in this area by combining acoustic telemetry with a correlated random walk model to try to examine potential morphological and behavioural factors that differentiate successful from unsuccessful migrants through Scotland's largest lake. Consistent with other studies, we found that smolts experienced a high rate of mortality in the lake $(\sim 43 \%)$, with approximately $14 \%$ potentially predated upon by birds and $4 \%$ by Northern pike. Migration speed in the lake was slow (the mean minimum movement speed between centres of activity was $0.13 \mathrm{~m} / \mathrm{s}$ ), and
\end{abstract}

Supplementary Information The online version contains supplementary material available at https://doi. org/10.1007/s10641-021-01172-x.

J. Lilly $(\bowtie) \cdot$ H. M. Honkanen · J. M. McCallum .

M. Newton · C. E. Adams

Scottish Centre for Ecology and the Natural Environment, IBAHCM, University of Glasgow, Rowardennan, Loch

Lomond, Glasgow G63 0AW, UK

e-mail: j.lilly.1@ research.gla.ac.uk

D. M. Bailey

College of Medical, Veterinary \& Life Sciences, Graham Kerr Building, University of Glasgow, Glasgow G12 8QQ, UK pathways frequently deviated away from the outlet river. There was no evidence of a morphological or behavioural trait or migratory pathway that distinguished successful from unsuccessful smolts. This suggests that migration movement direction in the main body of Loch Lomond appeared to be random. This was further supported by the output of a correlated random walk model which closely resembled the pathway and migration speed and distance patterns displayed by successful migrants. However, once successful smolts came within $\sim 2 \mathrm{~km}$ of the lake exit, a high proportion remained in this region prior to entering the River Leven. We suggest that this "goldilocks zone" is where directional cues become apparent to migrating fish. Future studies should combine random walk models with environmental variables to determine if external factors are driving the apparently random movement patterns exhibited by smolts in lakes.

Keywords Acoustic tags - Atlantic salmon . Migration $\cdot$ Lakes $\cdot$ Correlated random walk

\section{Introduction}

Migration is the process of animals transitioning amongst different environments, interspersed with periods of residency and can often vary based on life stage (Mueller and Fagan 2008; Avgar et al. 2014). Migration differs across temporal and spatial scales and 
across species and is often initiated by the need to avoid predation, mate or find food (Mueller and Fagan 2008; Avgar et al. 2014; Tamario et al. 2019). Long distance migration is relatively common in avian and marine animals, which often traverse large expanses of ocean to reach their feeding or mating grounds (Alerstam et al. 2003; Hunt et al. 2018; Horton et al. 2020; Vogel et al. 2021).

One group of animals that undergo long distance migrations through multiple habitat types are diadromous fishes (Limburg and Waldman 2009). A number of diadromous fish species have experienced dramatic declines throughout their range due to disruption of habitat connectivity due to anthropogenic barriers such as weirs, dams and hydropower facilities (Dadswell and Rulifson 1994; Birnie-Gauvin et al. 2018; Puijenbroek et al. 2019). Many freshwater systems have anthropogenic barriers impeding fish movement, as well as lakes that diadromous fishes must navigate through to reach the marine environment (Limburg and Waldman 2009; Nunn and Cowx 2012; Honkanen et al. 2018, 2021). How diadromous fishes navigate through standing waters is poorly understood (Honkanen et al. 2018; Lennox et al. 2021; Honkanen et al. 2021).

The Atlantic salmon, Salmo salar Linnaeus, 1758, is an anadromous species commonly studied because of its cultural and economic importance throughout Europe and North America and is a prime candidate to study migration behaviour through standing bodies of water (Klemetsen et al. 2003; Thorstad et al. 2012; Honkanen et al. 2018). Atlantic salmon populations are distributed throughout river systems draining into the North Atlantic, and many of these populations are currently listed as threatened or endangered (Thorstad et al. 2011). The focus of this paper is on the smolt stage of the Atlantic salmon life cycle. A smolt can be defined as a young freshwater salmonid that has undergone physiological and morphological changes that allow them to adapt to the marine environment (McCormick et al. 1985; Thorstad et al. 2012; Zydlewski et al. 2014). Loss rates during this life stage are high and have been reported to vary between 0.3 and $7.0 \%$ per km migration distance in river systems (Jepsen et al. 1998; Thorstad et al. 2012).

A large proportion of river catchments that support salmon populations flow through large freestanding bodies of water through which smolts must navigate before entering the marine environment
(Honkanen et al. 2018). For example, in Norway approximately $1 / 3$ of river systems drain through lakes (Hanssen 2020), and in Scotland, there are approximately 30,000 lakes many of which are components of Atlantic salmon rivers (Smith and Lyle 1979). Smolt riverine migration has been well studied and it has been reported that smolts utilize currents to rapidly migrate downstream towards the marine environment (Lacroix et al., 2004a, b; Svendsen et al. 2007; Davidsen et al. 2009). However, in standing bodies of water with a lack of directional flow, we do not know what cues smolts use, or behaviours they adopt, to successfully migrate through this environment (Honkanen et al. 2018; Hanssen 2020; Lennox et al. 2021). This is particularly important in interpreting how newly created standing waters (impoundments) may influence smolt migration success.

One technique that can help to further our understanding of smolt behaviour through standing bodies of water is passive acoustic telemetry (Honkanen et al. 2018, 2021; Hanssen 2020). This is a technique commonly used to assess the behaviour and survival of fishes (Hussey et al. 2015). The few studies utilizing acoustic telemetry to assess smolt migration through lakes have indicated that smolts experience disorientation and migration speed is slow (Aarestrup et al. 1999; Thorstad et al. 2011; Honkanen et al. 2018). Honkanen et al. (2018) assessed the movement of Atlantic salmon smolts $(n=10)$ through Loch Lomond, Scotland, using a small array of acoustic receivers $(n=10)$. The estimated loss rate of smolts through Loch Lomond was high (60\%). Additionally, smolts were reported to make frequent movements away from the exit point from the lake, travelling at a slow estimated rate of $\sim 0.05 \mathrm{~m} / \mathrm{s}$.

The high rates of mortality of smolts in lakes may be attributed, at least in part, to the lack of directional migration and energy expended in movements frequently away from the lake exit, thus ultimately increasing their risk of predation (Jepsen et al. 1998; Honkanen et al. 2018, 2021; Hanssen 2020). In riverine systems there has been conflicting information concerning which factors influence migration success of salmon. Most have noted that larger individuals with a high condition factor are more likely to be successful due to their increased ability to endure long distance migrations and evade predators (Kennedy et al. 2007; Tucker et al. 2016). To date no studies 
have assessed whether this is also a trend found in free-standing bodies of water.

This current study built on that of Honkanen et al. (2018) by increasing the effective resolution at which we were able to address several important questions regarding smolts behaviour in Loch Lomond. We did this by increasing the area over the lake which we were able to track fish. In addition, we improved the precision with which we were able to identify position in the lake. We used empirical data from this to compare some aspects of actual migration behaviour with that of a correlated random walk model. There were three main hypothesis of this study: (1) consistent with other studies, the loss rate of Atlantic salmon smolts through Loch Lomond would be high, specifically amongst small smolts with a low condition factor; (2) due to a potential lack of directional current in the main body of Loch Lomond, both successful and unsuccessful migrants would exhibit indirect migration pathways; (3) once near the lake outlet where the direction of the current flowing into the river may be detected, Atlantic salmon smolts would orientate towards the outflowing river and make a direct exit.

\section{Methods}

\section{Study area}

The Loch Lomond catchment in west/central Scotland has a total catchment area of $696 \mathrm{~km}^{2}$; approximately one-tenth of the catchment is contained in Loch Lomond lake (Murray and Pullar 1910, Fig. 1). Loch Lomond is the largest freshwater body in Britain, covering $71 \mathrm{~km}^{2}$ and has a maximum depth of $190 \mathrm{~m}$ (Maitland et al. 2000). The northern and southern portions of Loch Lomond are separated by the Highland Boundary Fault (Maitland et al. 2000). The northern lake is relatively narrow and deep, whereas the southern basin is shallow with many interspersed islands (Murray \& Pullar 1910; Maitland et al. 2000). Monthly mean temperatures in the lake range between 4 and $15{ }^{\circ} \mathrm{C}$ (Maitland et al. 2000). The River Endrick drains into Loch Lomond and is $49 \mathrm{~km}$ long (Maitland et al., 2000; Fig. 1). Loch Lomond drains into the River Leven ( $13 \mathrm{~km}$ long) which then discharges into the Firth of Clyde (Adams
1994; Fig. 5). The Firth of Clyde covers an area of approximately $100 \mathrm{~km}^{2}$ (Thurstan and Roberts 2010).

Acoustic telemetry

\section{Fish capture and tagging}

Between April 15 and 20, 2020, 125 Atlantic salmon smolts were captured in a 1.2-m rotary screw trap placed in the River Endrick (lat. 56.0492 ${ }^{\circ}$, long. $-4.43991^{\circ}$, Fig. 1). The trap was located $12.7 \mathrm{~km}$ upstream from the mouth of the River Endrick as it discharges into Loch Lomond. The trap was checked and emptied every day to ensure smolts did not remain in the trap for a prolonged period. For this study, Innovasea V7-2L tags were used; these have a weight and length of $1.5 \mathrm{~g}$ and $19.5 \mathrm{~mm}$, respectively. The tags emitted a coded sound signal at a frequency of $69 \mathrm{kHz}$ every $18-38 \mathrm{~s}$. The tags have a power output of $137 \mathrm{~dB}$ and an estimated tag life of 75 days. Tags were assumed to stop transmitting in the period June 29-July 4. After smolts were captured, they were anaesthetized in $0.1 \mathrm{~g} / \mathrm{L}$ of tricaine methanesulfonate (MS222) buffered with $0.1 \mathrm{~g} / \mathrm{L}$ of sodium bicarbonate. It took approximately $5 \mathrm{~min}$ for smolts to enter stage three anaesthesia (loss of equilibrium), which is a requirement for tagging. Smolts were then measured for weight $( \pm 0.1 \mathrm{~g})$ and length (fork length, mm) and a photograph taken for morphometric analysis. Surgical equipment was disinfected and rinsed with distilled water (Honkanen 2018). An approximately $10-\mathrm{mm}$ incision was made in the ventral abdominal wall, anterior to the pelvic girdle, and an Innovasea V7-2L $69 \mathrm{kHz}$ (Innovasea Ltd., Nova Scotia, Canada) coded transmitter was inserted into the abdominal cavity. Tagging was conducted under UK Home Office licence number PP0483054. Only Atlantic salmon smolts $>130$-mm fork length and $>20 \mathrm{~g}$ weight were tagged. During surgery water containing a low dose of MS222 and river water was used to ensure fish remained sedated. Incisions were closed by applying two interrupted surgeon knots with 4/0 Ethilon nylon sutures. Upon completion of tagging, smolts were placed back into a recovery tank, and once they began to exhibit normal swimming behaviour, they were placed into an in-river containment cage that had throughflow of freshwater. 


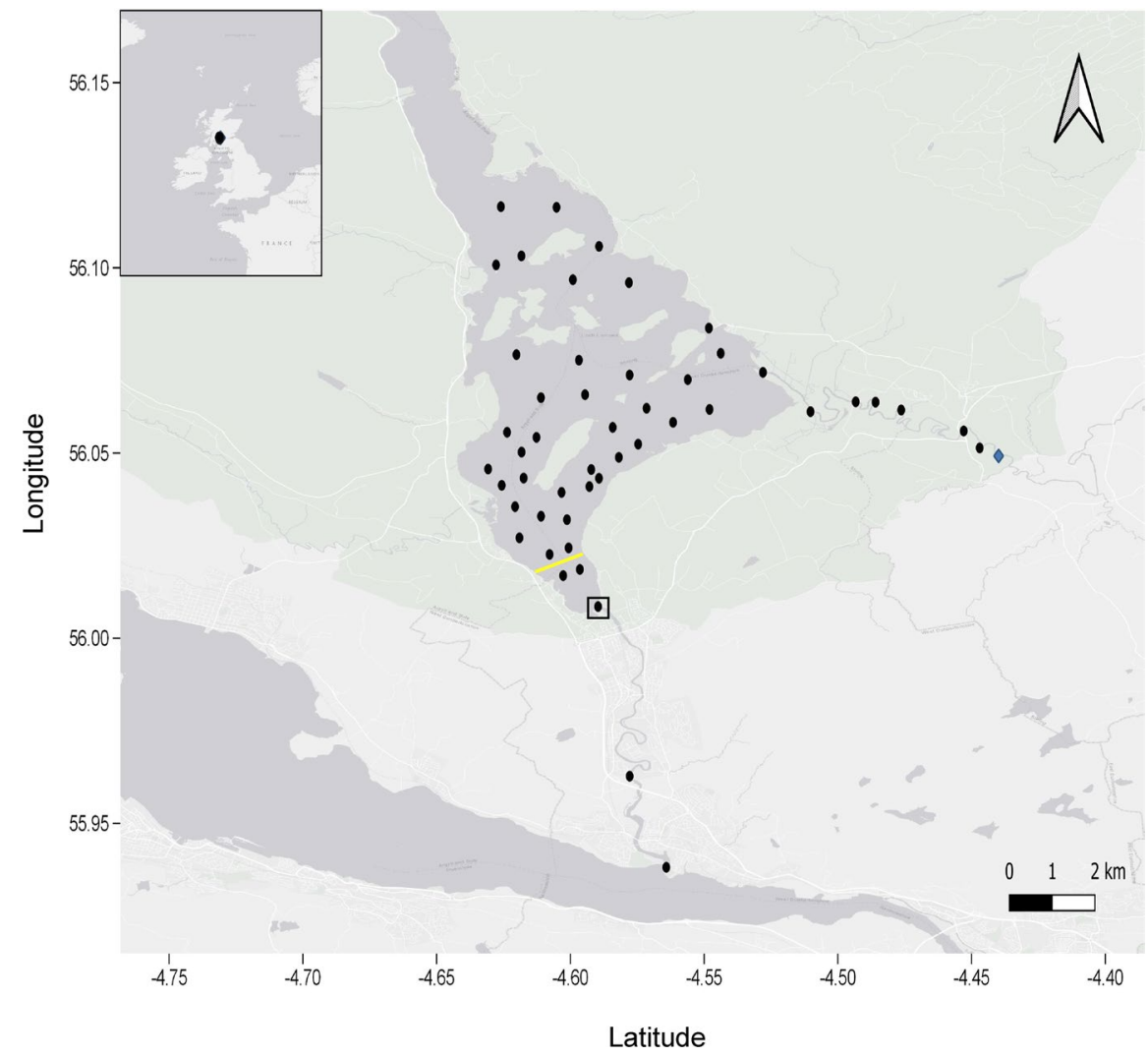

Fig. 1 Map of the Loch Lomond catchment including locations of acoustic receiver deployments during the period April 7-August 23, 2020, in the River Endrick $(n=7)$, from April 14 to October 13 in Loch Lomond $(n=39)$ and from April 11-August 22 in the River Leven $(n=3)$. The smolt trap in the River Endrick is represented by the blue diamond (lat. $56.0492^{\circ}$, long. $-4.43991^{\circ}$ ). The first acoustic receiver on the

Fish remained in the cage for approximately $30 \mathrm{~min}$ to ensure full recovery before release.

\section{Acoustic receiver deployment}

Sixty-nine kilohertz receivers deployed in this study consisted of three main types, VR2W, VR2Tx and VR2AR (Innovasea Ltd., Nova Scotia, Canada). VR2Ws only comprise a hydrophone and logger to record the unique ID of the fish, while VR2Tx receivers contain an additional temperature sensor. VR2ARs also provide tilt angle, temperature, depth and background noise readings (Reubens et al. 2019). VR2ARs also have an acoustic release that can be initiated upon receiving a signal at $69 \mathrm{kHz}$ emitted from a VR100 control device (Reubens et al. 2019). This
River Leven is represented by the black box (lat. $56.00812^{\circ}$, long. $-4.5886^{\circ}$ ), and the Goldilocks zone is represented by the area below the yellow line (see the "Results" section). The outer boundary of the Goldilocks zone was defined as the mean distance (mean $\pm \mathrm{SD} ; 1.75 \pm 0.8 \mathrm{~km}$ ) that successful smolts $(n=28)$ engaged in their final movement into the River Leven

decreases the effort required to retrieve receivers in deep water environments (Goossens et al. 2020).

Acoustic receivers deployed in the River Endrick and the River Leven consisted of VR2W (Endrick, $n=3$ ) and VR2Tx (Endrick, $n=4$; Leven, $n=3$ ), while acoustic receivers deployed in Loch Lomond consisted of VR2AR $(n=38)$ and VR2W $(n=1)$ acoustic receivers (Fig. 1). Acoustic receivers were deployed in the River Endrick and River Leven from April 7 to August 23 and April 11 to August 22, respectively. Acoustic receivers in Loch Lomond were deployed in a grid-like system from April 14 to October 13 (Fig. 1). Receivers in the River Endrick and River Leven were attached to a mooring comprising vertical steel pin on a $20 \mathrm{~kg}$ weight; the mooring was attached to chain which was anchored onto the 
shore. VR2AR receivers deployed in Loch Lomond were bolted onto an acoustic release canister (ARC; RS Aqua, UK) attached to a $35 \mathrm{~kg}$ weight and an anchor line holding the receiver approximately $1.5 \mathrm{~m}$ above the lakebed. The ARC lid was attached to three trawl floats which ensured the retrieval of the receivers and mooring upon initiation of the acoustic release (De Clippele and Risch 2021).

\section{Data analysis}

\section{False detections}

All analysis was conducted in R (R Development Core Team 2020). Detection data retrieved from receivers was filtered for false detections using the package GLATOS (Holbrook et al. 2018) using the shortinterval criterion. The short-term interval used in this study was calculated based upon the minimum delay of tags used using the methods outlined in Pincock (2012). Single detections at a receiver without a repeat within 14 min were removed from the analysis (Pincock 2012; Hayden et al. 2016).

\section{Smolt migration success}

\section{Unsuccessful smolts}

A successful smolt, that is one that successfully migrated through Loch Lomond, was defined as one detected having entered the loch from the River Endrick and later the first receiver in the outflowing River Leven (Fig. 1, lat. 56.00812 ${ }^{\circ}$, long. $-4.5886^{\circ}$ ) without having subsequent detections in Loch Lomond. Unsuccessful migrants were likely resident in the lake for longer than successful individuals. The three main potential predators of Atlantic salmon smolts in Loch Lomond are the avian piscivores Mergus merganser Linnaeus 1758 (the goosander), Phalacrocorax carbo (Linnaeus 1758) (the Great cormorant) and the fish Esox lucius Linnaeus 1758, (Northern pike) (Adams 1994). Potential avian predation was identified and defined as when tag detections skipped two intermediate receivers or where consecutive tag detections occurred within a time resulting in a speed of travel that was greater than the maximum swimming speed reported for an Atlantic salmon smolt (5.7 body lengths/s; Jepsen et al. 1998; Pedersen et al.
2008). Northern pike are common in Loch Lomond and are a primary aquatic predator of salmon smolts in lakes throughout Europe (Adams 1991; Jepsen et al. 1998; Kennedy et al. 2018). They are known to occupy small core home ranges (Guzzo et al. 2016); therefore, potential predation by a pike was defined as repeated consecutive detections between an adjacent group of receivers over at least 1 day, followed by repeated detections at one receiver until the end of the detection stream, indicating that the tag was likely passed by the predator (Weinz et al. 2020). There are additional species of predatory fish in Loch Lomond including Perca fluviatilis Linnaeus 1758 (perch) and piscivorous brown trout (Ferox trout), Salmo trutta Linnaeus 1758; however, predation of smolts by these species were assumed to be inconsequential in this study since perch in Scottish lakes have been reported to feed almost completely on benthic and planktonic invertebrates, and the abundance of Ferox trout in Scottish lakes is extremely low (Thorpe 1977; Thorne et al. 2016).

To avoid biasing a comparison of successful and unsuccessful migrant behaviour, fish that were potentially preyed upon were removed from the dataset, and the time of analysis was reduced for unsuccessful migrants. We thus filtered the data from unsuccessful migrants to include only detections from the time period up to $95 \% \mathrm{CI}$ of the duration that successful smolts occupied Loch Lomond. The period of time that successful smolts spent in Loch Lomond was calculated based upon their last detection on the final receiver in the River Endrick (Fig.1) and their first detection on the upstream receiver in the River Leven (Fig.1). This filtered dataset was used for all analysis of behaviour and space use of Atlantic salmon smolts in Loch Lomond.

\section{Smolt morphology}

Four metrics were used to determine if smolt loss rate was related to the morphology of all Atlantic salmon smolts that entered Loch Lomond; this included fork length ( $\mathrm{fl}$; mm), weight $(\mathrm{g})$, condition factor $(\mathrm{k})$ and tag burden. The condition factor of a smolt was calculated using the methods outlined in Barnham and Baxter (1998), and tag burden was calculated by dividing the weight of the tag $(1.5 \mathrm{~g})$ by the weight of the Atlantic salmon smolt (g) (Brown et al. 2013). 


\section{Smolt behaviour}

Centres of activity (COA) were calculated for successful and filtered unsuccessful migrant data to determine the location of smolts in Loch Lomond. COA positions are a measure of the mean position (latitude and longitude) of a fish obtained by weighting the detections of a fish between adjacent acoustic receivers with non-overlapping ranges during a specified duration of time (Simpfendorfer et al. 2002; Espinoza et al. 2015). The duration utilized for COA positions was $15 \mathrm{~min}$ and was determined using the methods outlined in Villegas-Rios et al. (2015) using data from smolts that completed successful migrations into the River Leven $(n=28)$. COA positions were calculated using the COA function in the Animal Tracking Toolbox (ATT) for R (Udyawer et al. 2018, R Development Core Team 2020). COA position data was used to calculate Atlantic salmon smolts non-resident events, behavioural metrics and space use in Loch Lomond. Estimates of position using COA while not providing as precise a location as alternatives such as VEMCO Positioning System (VPS) or YAPS (Yet Another Positioning Solver) (Baktoft et al. 2017; Guzzo et al. 2018) were used in this study because the receiver density required for these more precise positioning methods could not be accommodated without loss of geographic coverage in this relatively large lake $\left(71 \mathrm{~km}^{2}\right)$. As the risk of losing fish from the study area (i.e. into the area of the lake not instrumented by receivers) in this study was high, thus fish location estimation precision was exchanged for an extended detection zone and thus greater study area.

Several behavioural metrics were defined from multiple measures of COA positions. A non-residence event is defined as the movement of a salmon smolt between two COA positions and is referred to as a "movement" for the remainder of the manuscript. Movements were identified using the RunResidenceExtraction function in the VTrack package in $\mathrm{R}$ (Campbell 2013).

The timing of smolt movement into, and out of, Loch Lomond was determined by their time of emigration from the River Endrick and last detection on the first River Leven receiver, respectively (Fig.1). The hour of entry into Loch Lomond comprised the frequency of all Atlantic salmon smolts that successfully migrated out of the River Endrick and into Loch
Lomond for that hour of the day across the whole migration period, while movement patterns within and out of Loch Lomond only comprised data from successful migrants. Sunset and sunset times over the duration of the study were extracted from the getSunlightTimes function in the package suncalc (Thieurmel and Elmarhraoui 2019). Days were split into three periods as defined by Hanssen (2020) and included dim periods (interval of $2 \mathrm{~h}$ after sunrise and before sunset), daytime hours (between the dim periods) and nighttime hours (between sunset and sunrise).

Additional behavioural metrics assessed in this study included the maximum distance detected away from the River Leven; this was measured as the furthest COA position an Atlantic salmon smolt was detected in Loch Lomond as measured from the River Leven exit. The estimated minimum total distance travelled is the summation of distances between all measures of COA positions, while the smolt was in the study area of Loch Lomond. As fish position was not estimated constantly but only when the fish was within detection range of a receiver and that a straight-line movement between two COA positions was unlikely; this estimate of distance travelled is realistically only an estimate of the minimum distance travelled and likely lower than the actual distance travelled. Relative turning angle is the change in direction $\left(^{\circ}\right)$ of a smolt relative to its previous movement. The relative turning angle was converted to a circular object using the circular function in the circular package in R (Agostinelli and Lund 2017), and the mean turning angle was calculated for each smolt. Estimated minimum total number of turns made by each smolt over their entire migration route was the number of movements that resulted in a relative turning angle greater than $0^{\circ}$ (i.e. a straight line). These metrics were calculated using the as.ltraj function in the adehabitatLT package in $\mathrm{R}$ (Calenge 2006). Again, because of the study design, the fact that position was not constantly estimated and that fish were unlikely to always take a direct route from one COA position to another, the estimated minimum total number of turns is very likely less than the actual number of turns made by each fish. Although less clear, it is possible that the relative turning angle measured is unlikely to include all turns taken for each fish; however, it is unlikely that this estimate is directionally biased. Lastly, the estimated average 
minimum speed at which successful Atlantic salmon smolts swam through Loch Lomond was estimated by dividing the total distance travelled between successive COA positions by the duration of the lake migration from the River Endrick to the River Leven. As with other metrics above and based upon minimum estimates of distance travelled but a relatively exact measure of time elapsed, the average speed is thus a minimum estimated speed of travel.

\section{Smolt space use}

To assess Atlantic salmon smolt space use in Loch Lomond, we calculated their core $(50 \%)$ and extended (90\%) home ranges (kernel utilization distribution (KUDs)) using the adehabitathr package (Calenge 2006). A land barrier polygon was used to remove any portions of the KUDs that would overlap with land (Duffing Romero et al. 2021). In addition, trajectories of smolts were overlaid on a map of Loch Lomond using the plot.ltraj function (Calenge 2006).

Lastly, the final migratory trajectory of successful smolts was extracted based on a direct trajectory from Loch Lomond into the River Leven (Fig. 1). The mean distance from which successful smolts initiated a direct trajectory into the River Leven from Loch Lomond was determined by using the ComputeDistance function in the $\mathrm{R}$ package VTrack (Campbell 2013), and this marked the outer edge of the "goldilocks zone" (a reference to the fact that the cues enabling the fish to find the lake exit (i.e. the entrance to the River Leven) were at this point presumed to be "just right").

\section{Statistical analysis}

\section{Morphological predictors of migration success}

A binomial GLM model was used to determine whether morphological factors (fork length, weight, condition factor ( $\mathrm{k})$, tag burden) influenced the potential mortality of smolts in the lake (Lothian et al. 2018). Collinearity amongst variables was assessed using Spearman's rank correlation tests. Fork length was highly correlated with weight $(r=0.89)$ and tag burden $(r=-0.81)$. Therefore, only fork length and condition factor were included in the GLM. The top candidate models were obtained using the "glmulti" (Calcagno 2020) package and compared using bias-corrected second-order information criterion $\left(\mathrm{AIC}_{\mathrm{c}}\right.$ ) (Burnett et al. 2013). Likelihood ratio tests were then used to determine the final model by comparing the models with and without explanatory variables (Burnett et al. 2013).

\section{Timing of migration}

A Rayleigh test of uniformity was performed using the r.test in the CircStats package (Lund and Agostinelli 2018) to determine if the movement of smolts moved into, and out of, Loch Lomond was evenly distributed throughout all hours of the day. Hour of the day was converted to radians prior to performing the test using the hms2rad function in the package astroFns in $\mathrm{R}$ (Harris 2012).

\section{Behavioural predictors of migration success}

A binomial GLM was used to determine whether behavioural factors (average relative turning angle $\left(^{\circ}\right.$ ), estimated minimum total number of turns, maximum distance away from the Leven (m) and estimated minimum total distance travelled (m)) influenced the successful migration of smolts through Loch Lomond (Lothian et al. 2018). Model selection procedures were the same as the model previously discussed.

\section{Comparison of space use}

Comparisons between the size of core (50\% KUD) and extended (95\% KUD) home ranges of successful and unsuccessful migrants were calculated using a Wilcoxon rank sum test.

To determine if the Goldilocks zone served as a unique region utilized by successful smolts, the proportion of unsuccessful migrants that entered this area was calculated. Additionally, once successful smolts entered the Goldilocks zone, the proportion of movements that occurred in this zone was compared to the number movements that resulted in movement northwards and thus away from the lake exit and out of this zone, using a paired Wilcoxon signed-rank test.

\section{Random walk model}

To test if Atlantic salmon smolts are migrating through random lake movements, a random walk 
model from the glatos package (Holbrook et al. 2018) in $R$ was used to simulate correlated random walks (CRW) within the boundary of Loch Lomond. A CRW model was chosen as it reflects an animal's tendency to move, where the direction of each new step is correlated with the previous one. Simulated paths followed the assumption that the turning angle for sequential directional movements was drawn from a Gaussian distribution with mean $(\mu)$ and standard deviation $(\sigma)$. For the walk to be correlated, $\mu$ was always set to 0 , and five levels of $\sigma$ were modelled separately in increments of $5^{\circ}\left(5,10,15,20,25^{\circ}\right)$. A range of $\sigma$ was tested to (1) determine how varying turning angle in evenly spaced increments influenced migration success and (2) to find a value that resulted in a random walk that most closely resembled the estimated empirical data on minimum distance travelled and duration spent in Loch Lomond by successful Atlantic salmon smolt migrants in this study.

Step lengths were set to $0.05 \mathrm{~km}$ and assumed to be constant (Hanssen 2020). The number of steps each model simulated was set to a maximum of 1500 . This meant that the maximum distance simulations could travel would not exceed $75 \mathrm{~km}$ and would therefore allow an approximate comparison with the measured distance travelled by successful smolts in this study. The starting location for the simulations was set as the point where the River Endrick discharges into Loch Lomond with an initial bearing of $301^{\circ}$ from north (the direction of inflowing water from the River Endrick to Loch Lomond). The end point for the simulation was set to encompass the detection area covered by the first receiver located on the outflowing River Leven (lat. 56.00812 ${ }^{\circ}$, long. $-4.5886^{\circ}$, Fig. 1). When a simulated track reached this region, it was classed as a successful simulated migration; tracks that did not reach this point were deemed to be an unsuccessful simulated migration.

For each of the five $\sigma$ values, 200 migration simulations were generated. The distance travelled for each simulated individual was calculated by multiplying the step length $(0.05 \mathrm{~km})$ by the total number of steps taken to reach the detection zone of first River Leven receiver (Fig.1). There is a lack of information concerning the accurate swim speeds (body lengths/s) of Atlantic salmon smolts through free-standing bodies of water. Therefore, the swim speed set for the simulated Atlantic salmon smolts in this study was derived from a study tracking hatchery post-smolts through a fjord system that showed a mean swimming speed of smolts was 1.2 body lengths.s ${ }^{-1}$ (Thorstad, 2004). The mean absolute swimming speed of simulated smolts was calculated using (Hanssen 2020):

$V=1.2$ body lengths $\mathrm{s}^{-1} *(\mathrm{Lm})$

where $L_{m}$ is the mean fork length of Atlantic salmon smolts that successfully migrated through Loch Lomond $(n=49$, mean $=0.145 \mathrm{~m})$ and $V$ is equal to the swim speed in $\mathrm{m} . \mathrm{s}^{-1}$. Therefore, the estimated swim speed of simulated smolts was $0.17 \mathrm{~m} . \mathrm{s}^{-1}$. This assumes a constant swim speed over $24 \mathrm{~h}$. Telemetry data of real Atlantic salmon smolts indicated that movement predominantly occurs at night (Kennedy et al. 2018); thus, in some simulations, migration speed was halved to account for possible inactivity during the day, (assuming $12 \mathrm{~h}$ of daylight). Essentially this simulated $12 \mathrm{~h}$ of movement followed by $12 \mathrm{~h}$ of inactivity (Hanssen 2020).

\section{Results}

Mortality

Of all smolts tagged and released in the River Endrick $\quad(n=125), \quad 39 \% \quad(n=49) \quad$ successfully migrated into Loch Lomond. Fifty-seven percent $(n=28)$ of lake migrants $(n=49)$ successfully migrated out of the lake. Of those fish that migrated in the lake $(n=49), 18 \%(n=9)$ were likely preyed upon, with $14 \%(n=7)$ which were likely predated upon by a bird and $4 \%(n=2)$ by Northern pike. The remaining causes of mortality $(n=12)$ are unknown, as these tags exhibited normal smolt behaviour up until detections ceased.

The average fork length of Atlantic salmon smolts that successfully migrated $(n=49)$ into Loch Lomond was $145.47 \pm 12.29 \mathrm{~mm}$ (mean $\pm \mathrm{SD}$; range: 130-206). A binomial regression model assessing the effect of morphological factors included fork length and condition factor (weight and tag burden were highly correlated with included variables) and showed that migration success was not dependent on the condition factor $(k ; t=0.94, p=0.76)$ or the fork length of the smolt (FL; $t=-0.03, p=0.22$ ). 
Migration timing

On average, smolts were detected $10.09 \pm 9.33$ (range: 1-54) times on $1.49 \pm 0.87$ (range: $1-7$ ) receivers for each case where a COA position could be measured. Successful smolt migration through Loch Lomond was slow; on average, successful smolts migrated at an estimated average minimum speed of $0.13 \mathrm{~m}$. $\mathrm{s}^{-1} \pm 0.04 \mathrm{~m} . \mathrm{s}^{-1}$ over 5.23 \pm 4.2 days (0.86-21.90; mean $\pm \mathrm{SD})$. The migration into Loch Lomond $(n=49)$ and the initiation of a movement once in the lake ( $n=2879$ observed movements) were dependent on the hour of the day (entrance: Rayleigh test, r.bar $=0.59$, Fig. 2a, $p<0.01$; In: r.bar $=0.24$, $p<0.01$; Fig. 2b). Occurring primarily during the day (Day, $n=40,83.0 \%$; Dim, $n=7,14.30 \%$; Night, $\mathrm{n}=2,4.08 \%$; Fig. 2A), with a mean entrance time of 13:00 British Summer Time (BST, GMT+1). In contrast migration out $(n=28)$ of Loch Lomond was not dependent upon the time of the day (Rayleigh test: r.bar $=0.24, p=0.20$; Fig. 2c). Migrations in Loch Lomond itself occurred primary during the night (day, $n=921,16 \%$; dim, $n=446,7.9 \%$; night, $n=1512,27 \%$ ), with the mean time of movement being 3:00 BST (Fig. 2b).

\section{Behavioural predictors of migration success}

Nine unsuccessful migrants were included in the analyses comparing the behaviour and space use of Atlantic salmon smolts in Loch Lomond, since the time they spent in the lake was within the $95 \%$ CI duration in which successful smolts were detected (6.02 days). The estimated minimum total distance smolts travelled and their estimated minimum frequency of turns were highly correlated $(r=0.86)$; therefore, only the estimated minimum total distance travelled was included in the model assessing behavioural factors influencing migration success. The logistic regression model included the mean relative turning angle, estimated minimum total distance travelled and the maximum distance a fish was detected at any point in time from the River Leven. The final model showed that migration success was not dependent on their relative turning angle $(t=-0.51, p=0.16)$, estimated minimum total distance travelled $\left(t=1.3 \times 10^{-3}, p=0.90\right)$ or maximum distance detected away from the Leven $(t=-0.41, p=0.22)$.
Home range

Successful $(n=28)$ and unsuccessful $(n=9)$ migrants did not differ in their space use of Loch Lomond, mainly utilizing the mid and lower reaches of the lake (Fig. 3). However, one successful (ID: 36568) and two unsuccessful migrants (ID: 36556, 36496) had core utilization distributions that occurred near the most northern receivers in our study (Fig. 3). There was no significant difference between the size of the core (successful, $5.66 \pm 2.95 \mathrm{~km}^{2}$, Fig. 3a; unsuccessful, $5.62 \pm 3.03 \mathrm{~km}^{2}$, Fig. 3b) and extended (successful, 16.72 $\pm 7.02 \mathrm{~km}^{2}$, Fig. 3a; unsuccessful, $15.74 \pm 7.39 \mathrm{~km}^{2}$, Fig. 3b) space use distributions of successful and unsuccessful migrants (Wilcoxon sum rank test; KUD 50, $n=37, p=0.82$; KUD 95, $n=37$, $p=0.85$; Fig. 3 ).

Migration trajectories

On average, successful smolts $(n=28)$ travelled an estimated minimum total distance of $55.87 \pm 49.52 \mathrm{~km}$ in the lake and were detected for $5.23 \pm 4.20$ days (mean \pm SD. There was no one distinct migratory pathway that was unique to successful smolts (Supplementary Material- Fig. 1S). Examples of migration route amongst successful smolts: one individual (ID: 36662) made a direct migration towards the River Leven travelling an estimated minimum distance of approximately $16.86 \mathrm{~km}$ over 0.86 days (Fig. 4a). Another successful individual (ID: 36553) travelled around the most southerly island before making an exit (Fig. 4b). This smolt travelled an estimated minimum distance of $35.42 \mathrm{~km}$ over 5.94 days. Lastly, one smolt (ID: 36568) migrated quite far north, travelling an estimated minimum total distance of $245.82 \mathrm{~km}$ over a duration of 21.90 days (Fig. 4c).

Unsuccessful migrants displayed similar variation in movement patterns as for successful smolts (Supplementary Material- Fig. 2S). For example, after exiting the River Endrick, one smolt (ID: 36589) made a direct movement towards the River Leven prior to making repetitive back movements in the southern portion of the lake (Fig. 4d). A second smolt (ID: 36526) made a circular migration of an estimated minimum distance of $72.57 \mathrm{~km}$ over 6.04 days around the island of Inchmurrin (Fig. 4e). Lastly, like one successful smolt, an unsuccessful 

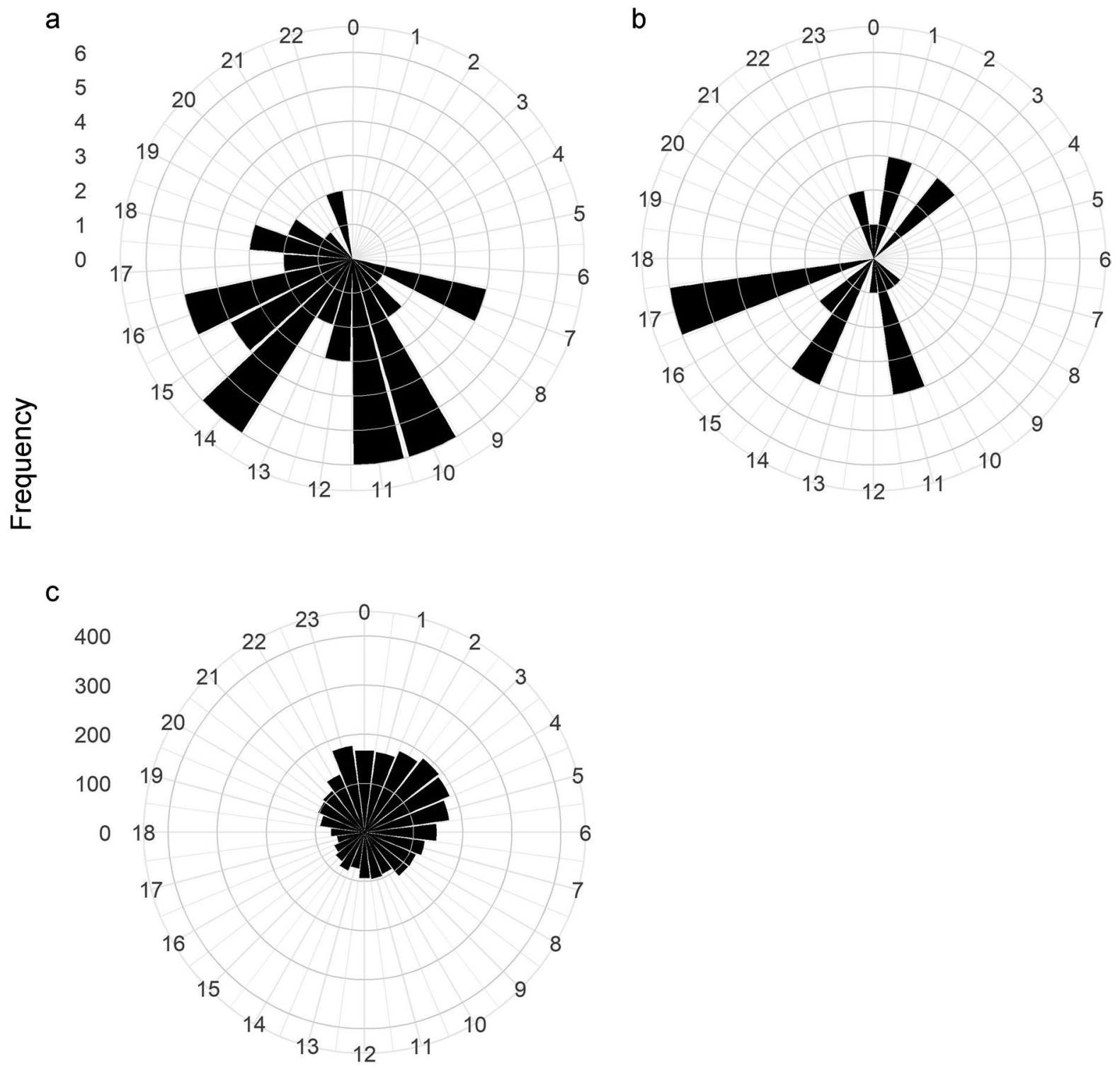

Fig. 2 Circular plots depicting the hour (British Summer Time; BST) smolts were last detected on the final receiver in the River Endrick $(n=49 ; \mathbf{a})$, the initial receiver in the River Leven $(n=28 ; \mathbf{b})$ and the initiation of a movement by a successful migrant in Loch Lomond $(n=2879$; c). The hour of entry into Loch Lomond comprised data on all Atlantic salmon smolts that successfully migrated out of the River Endrick

individual migrated to the northernmost portion of the receiver range (ID:36496) travelling an estimated minimum distance of $66.01 \mathrm{~km}$ over 6.06 days (Fig. 4f) but ultimately did not successfully migrate out of Loch Lomond. and into Loch Lomond ( $n=49$ ), while movements within and out of Loch Lomond only comprised data from successful migrants. The hour Atlantic salmon smolts initiated a movement in Loch Lomond which was determined based upon the start of a non-residency event for smolts that were known to successfully migrate into the River Leven $(n=28)$

\section{Goldilocks zone}

Once Atlantic salmon smolts entered the River Leven, they were not detected returning to Loch Lomond. The point in the lake at which successful 
a

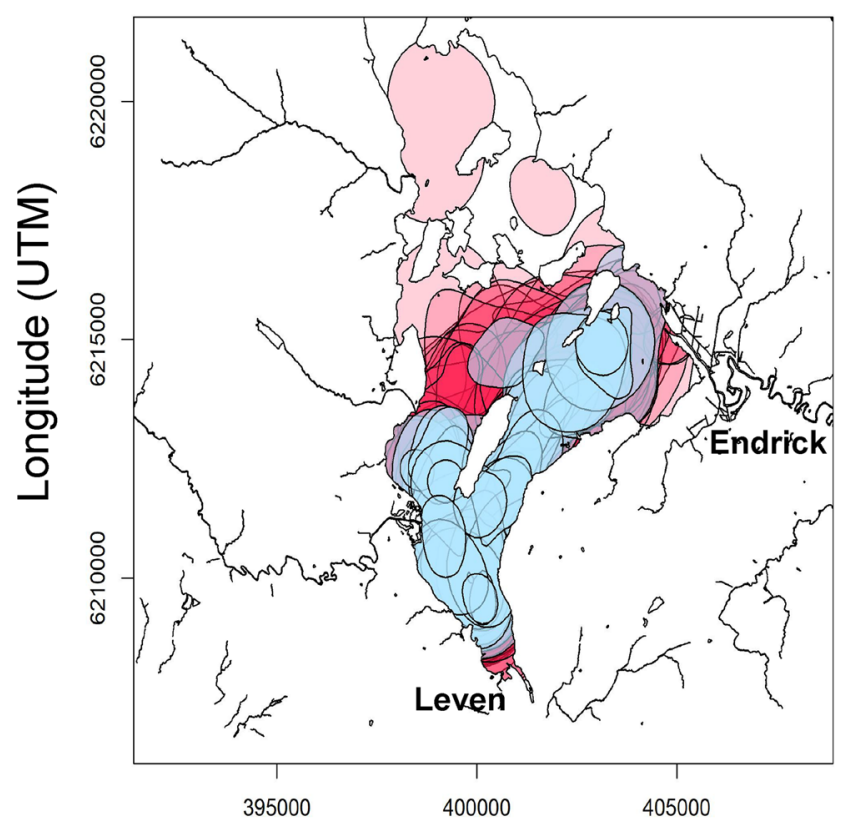

b

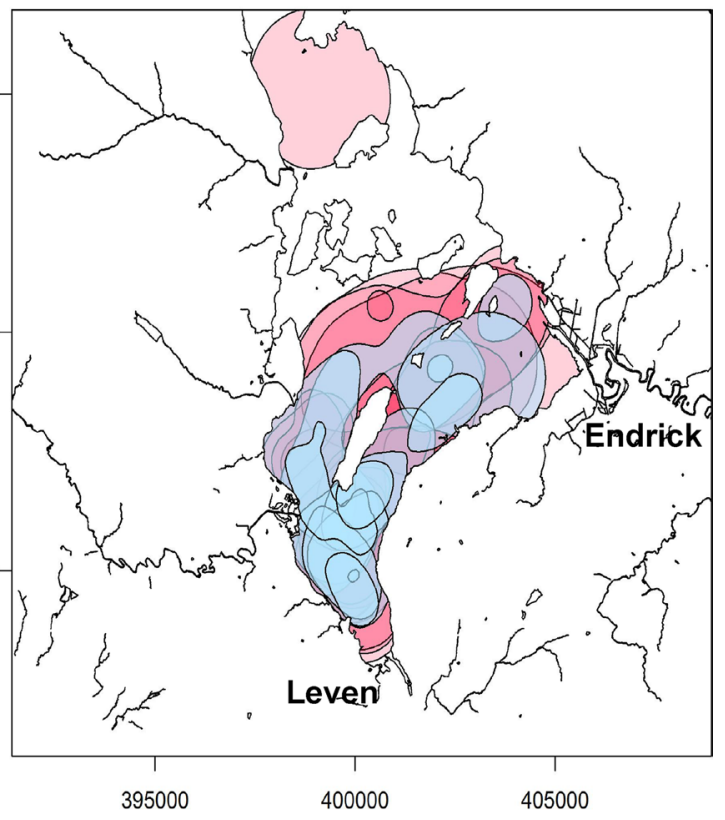

Latitude (UTM)

Fig. 3 Map displaying the home ranges of successful $(n=28$; a) and unsuccessful $(n=9 ; \mathbf{b})$ migrants in Loch Lomond (UTM Zone $30 \mathrm{U}$ ). Blue regions represent 50\% utilization distributions (KUD) of Atlantic salmon smolts in Loch Lomond, whereas the red regions represent their 90\% KUD. KUD calculations were based upon the centre of activity (COA) calcu-

smolts $(n=28)$ made a direct movement into the River Leven occurred at an average estimated minimum distance of $1.75 \pm 0.80 \mathrm{~km}$ (mean $\pm \mathrm{SD}$; range: 1.19-4.27) away from the lake exit. We define this point as representing the outer bounds of the Goldilocks zone (Fig. 1). These exit trajectories took a mean duration of $7.58 \pm 12.89 \mathrm{~h}$ (mean $\pm \mathrm{SD}$; range: 0.75-60 h). Once fish entered the Goldilocks zone, $67 \%(n=19)$ of smolts made movements that resulted in migrating northwards outside of the zone. The remaining $29 \%(n=8)$ only engaged in movements in the Goldilocks zone prior to migrating into the Leven. Successful Atlantic salmon smolts had a significantly higher number of movements in the Goldilocks zone $(n=19,6.58 \pm 6.82$ (range: $0-24)$ ) than movements that resulted in migrating northwards and outside the Goldilocks zone $(n=19,2.89 \pm 0.53$ (range: $1-7)$; paired Wilcoxon signed rank test, $V=111, p=0.04$ ). However, $56 \% \quad(n=5)$ of unsuccessful migrants entered this area, suggesting entry to the Goldilocks lations for salmon smolts in 15-min intervals. The dataset of unsuccessful migrants was filtered to include only detections within the $95 \%$ confidence interval (CI) of the time successful smolts occupied Loch Lomond. This was calculated based upon their last detection on the final receiver in the River Endrick and initial receiver on the River Leven

zone does not guarantee successful migration out of the zone.

\section{Random walk model}

The current study did not allow for accurate measures of the actual swim speed of smolts in Loch Lomond (only estimated minimum speed between two known points). Thus, swim speeds and step lengths utilized for the simulated smolts were derived from the literature (Hanssen 2020). The simulated swim speed of a smolt in Loch Lomond $\left(0.17 \mathrm{~m} . \mathrm{s}^{-1}\right)$ was derived from the speed $\left(\mathrm{bl} . \mathrm{s}^{-1}\right)$ of smolts in the standing water of a ford system as described in Thorpe et al. (1981). Assuming a constant swimming speed of $0.17 \mathrm{~m}$. $\mathrm{s}^{-1}$ and step length of $0.05 \mathrm{~km}$ through both day and night, random walk simulations beginning at the mouth of the inflowing River Endrick and terminating at the outflowing River Leven, revealed a positive correlation between the increasing turn angle $(\sigma$; 
a
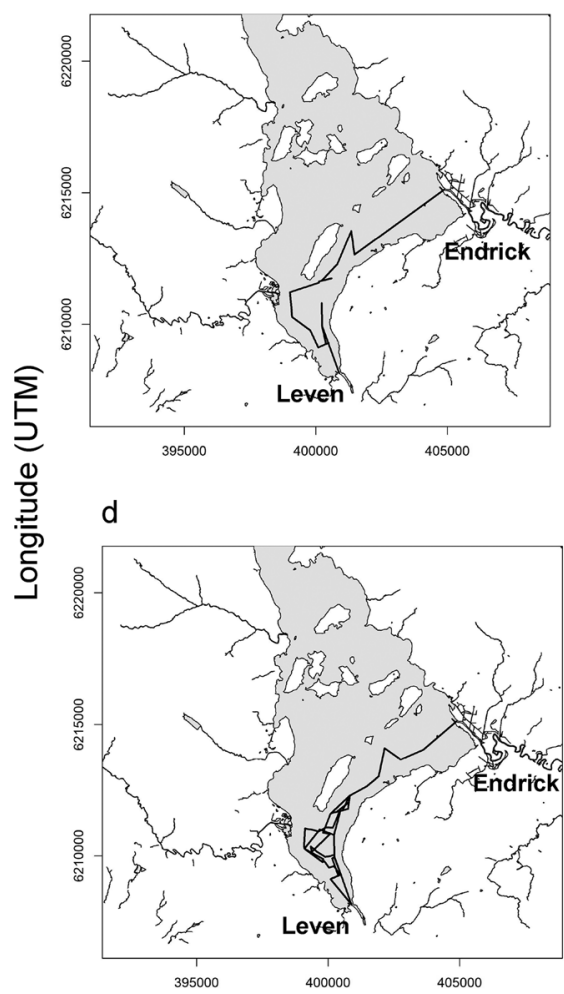

b

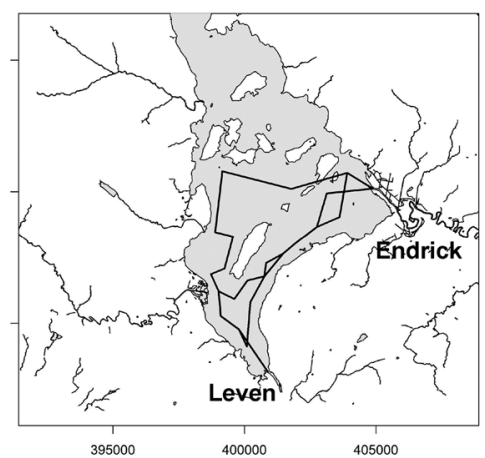

e

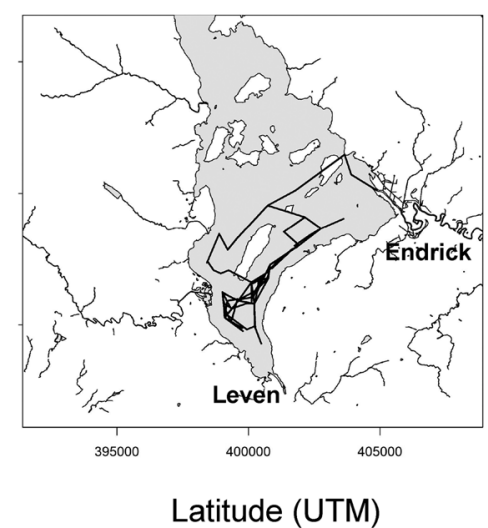

C

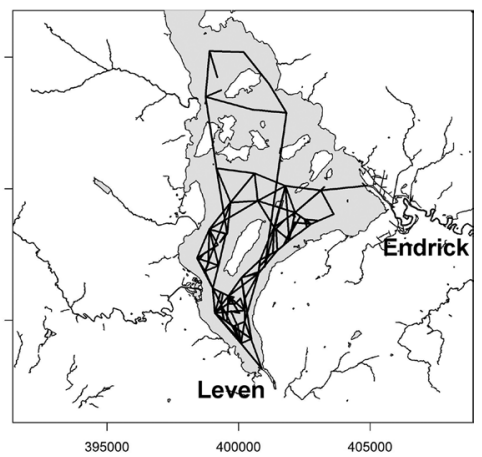

f

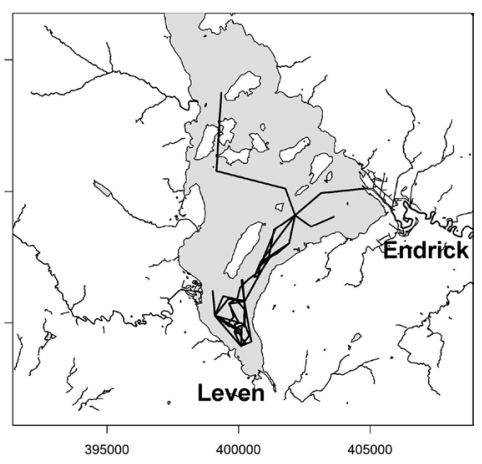

Fig. 4 Examples of successful $(n=28$; a 36662, b 36553, c $36568)$ and unsuccessful migrants $(n=9$; d 36589, e 36526, f 36496) displaying different migratory patterns in Loch Lomond during 2020 (UTM Zone $30 \mathrm{U}$ ). The dataset of unsuccessful migrants was filtered to include detections that

$5,10,15,20,25)$ of a simulated smolt and the success rate, duration and total distance travelled through Loch Lomond (Table 1; Fig. 5). For simulations accounting for diurnal migration, the mean travel time for all turning angle groups doubled (Table 1). When excluding nocturnal migration, simulations with a turning angle $\sigma$ of 15 (58.54 km over 3.98 days; Table 1; Fig. 5) were found to result in a model that best fit empirical data of the minimum estimated mean distance travelled, and time taken resulting in $55.87 \mathrm{~km}$ over 5.23 days.

\section{Simulated tracks}

Consistent with the tracks displayed by actual successful smolts in this study, simulated smolts with a $\sigma$ of 15 displayed varying migratory pathways to extended to the $95 \%$ confidence interval (CI) of the duration successful smolts which occupied Loch Lomond. The time successful smolts spent in Loch Lomond was calculated based upon their last detection on the final receiver in the River Endrick and initial receiver on the River Leven

reach the lake outlet. We present four examples here; one simulated smolt (Fig. 6a) travelled $51.5 \mathrm{~km}$ over 3.51 days, following a similar trajectory to ID:36662 (Fig. 4a) albeit at a slower pace, whereas another (Fig. 6b), travelled $69.5 \mathrm{~km}$, spending a large portion of time around the most southerly island in the lake before exiting the River Leven after 4.73 days. Another simulated smolt (Fig. 6c) travelled 44.15 over 3 days and travelled in a fairly linear path at the start of their migration but spent a considerable amount of time in the southern portion of the lake before exiting. The last simulated smolt (Fig. 6d) travelled $72.35 \mathrm{~km}$ over 4.93 days and displayed the most erratic path of the four simulated smolts, heading northwards upon exiting the River Endrick and spending time around the most southerly island before heading in the direction of the outflowing river. 
Table 1 Results from correlated random walk models of simulated Atlantic salmon smolts in Loch Lomond. This includes the success rate $(\%)$, mean distance travelled and mean duration of loch migration for each simulation group. Simulations were assigned a maximum number of 1500 steps with a length of $0.05 \mathrm{~km}$. Simulated paths assumed a mean $(\mu)$ turning angle of 0 , and the standard deviations of turning angles $(\sigma)$ consisted of five groups $(5,10,15,20,25)$. For each of the five groups, 200 simulations were generated. The estimated swim speed of simulated smolts was $0.17 \mathrm{~m} . \mathrm{s}^{-1}$, and to account for diurnal migration, the swim speed was halved $\left(0.085 \mathrm{~m} . \mathrm{s}^{-1}\right)$

\begin{tabular}{lllll}
\hline Turning angle $(\sigma)$ & Success \% (no.) & Mean distance $(\mathrm{km})$ & $\begin{array}{l}\text { Mean duration at } 0.17 \mathrm{~m} . \mathrm{s}^{-1} \\
\text { (days) }\end{array}$ & $\begin{array}{l}\text { Mean duration } \\
\text { at } 0.085 \mathrm{~m} . \mathrm{s}^{-1} \\
(\text { days })\end{array}$ \\
\hline 5 & $14.5(29)$ & 46.33 & 3.15 & 6.31 \\
10 & $5.5(11)$ & 42.80 & 2.91 & 5.83 \\
15 & $4(8)$ & 58.54 & 3.98 & 7.96 \\
20 & $1.5(3)$ & 60.22 & 4.1 & 8.2 \\
25 & 0 & NA & NA & NA \\
\hline
\end{tabular}

a

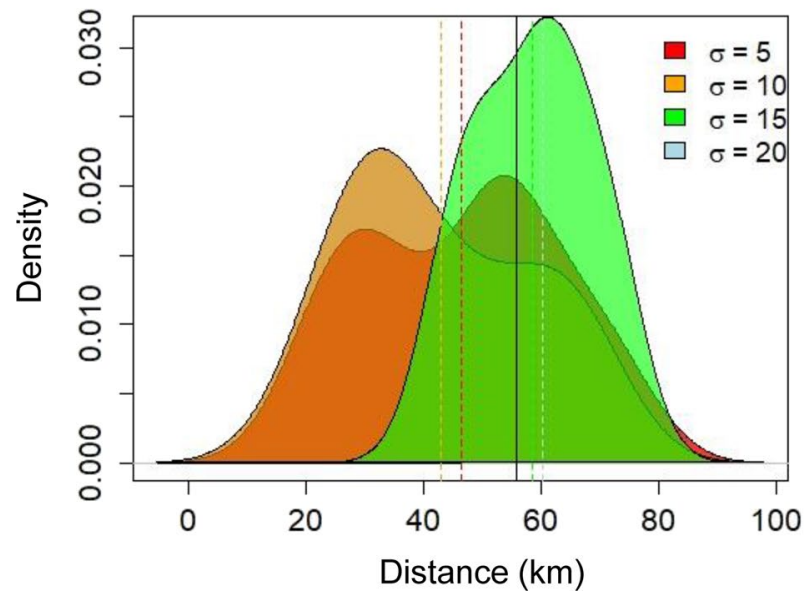

Fig. 5 Graphs displaying results from correlated random walk models of simulated Atlantic salmon smolts in Loch Lomond including the density of the distance travelled $(\mathrm{km} ; \mathbf{a})$ and the duration (days) of simulated smolt tracks. Simulations were assigned a maximum number of 1500 steps with a length of $0.05 \mathrm{~km}$. Simulated paths assumed a mean $(\mu)$ turning angle of 0 but drawn from a normal distribution of turning angles of with standard deviations $(\sigma)$ from five groups $(5,10,15,20$,

\section{Discussion}

Loss rates of acoustically tagged salmonid smolts in free-standing bodies of water have been reported to be as high as $88 \%$ (Jepsen et al. 1998). Consistent with other studies, here we provide further evidence that the loss rate of Atlantic salmon smolts through large free-standing bodies of water is substantial (Berry 1933; Thorpe et al. 1981; Bourgeois and O'Connell

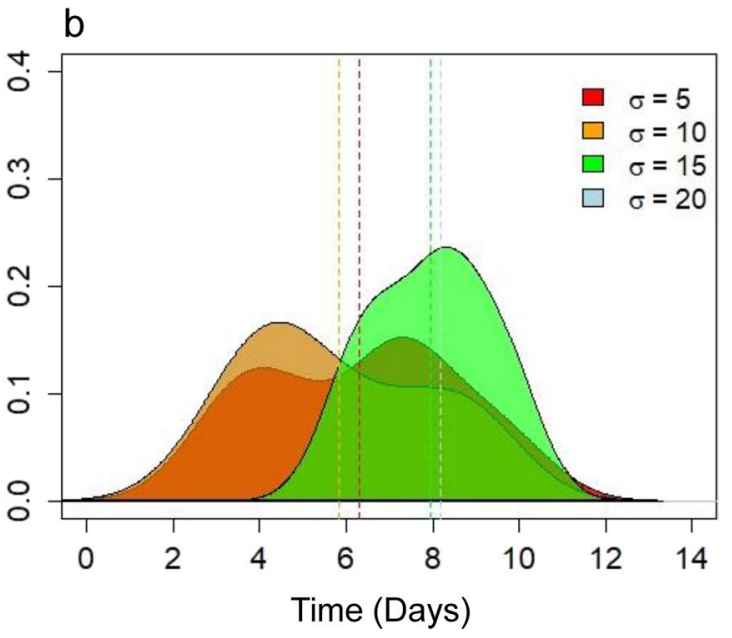

$25)$. The $25^{\circ}$ group was not included in the figure as no simulated smolts in this group completed a successful migration into the River Leven. For each of the five groups, 200 simulations were generated. The estimated swim speed of simulated smolts was $0.17 \mathrm{~m} . \mathrm{s}^{-1}$. The black line in both plots is the estimated average minimum distance (a) and duration of successful smolts in Loch Lomond

1988; Aarestrup et al. 1999; Honkanen et al. 2021). The likelihood of Atlantic salmon smolts released from the River Endrick $(n=125)$ and completing a successful migration through the Loch Lomond was very low, with only $57 \%(n=28)$ being detected in the River Leven. The highest loss rate occurred within the Endrick, with only 39\% (n=49) successfully migrating into Loch Lomond. This is consistent with Honkanen et al. (2018) who reported a smolt loss 


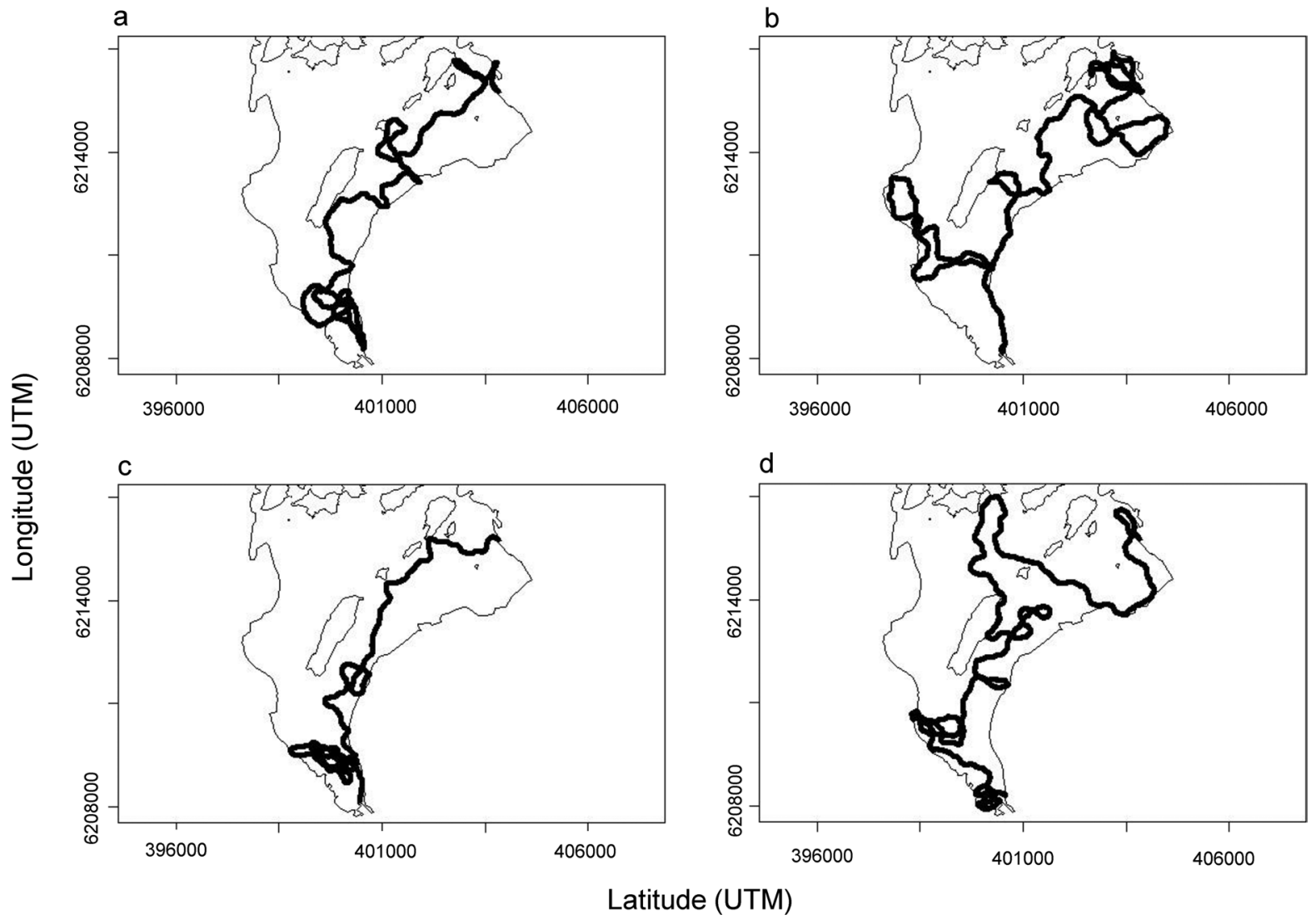

Fig. 6 Simulated tracks for four successful smolts (a, b, c, d) with a turning angle $\sigma$ of 15 and step length of $0.05 \mathrm{~km}$, moving at $0.17 \mathrm{~m} / \mathrm{s}$. Successful smolts were defined as those

rate of $40 \%$ in the Endrick. It is unlikely that the high mortality rates in this region were related to environmental parameters such as water level as the variation in flow rate in the Endrick is low across years and very low within the period of this study (SEPA, 2021). Additionally, the average water level during the dates when successful lake migrants exited the Endrick (0.41 m, April 17-May 19) was similar to the average water level that would have been experienced by smolts during this study $(0.55 \mathrm{~m}$, April $15-$ August 23 ), indicating that the water level during the study period was sufficient for smolts to exit the River Endrick.

A recent study has shown that smolt mortality during migration in the River Endrick is mainly the result of high rates of avian and piscine predation (Chavarie et al. submitted). The high loss rates of salmon smolts in Loch Lomond may in part also be which were detected in the region covered by the first acoustic receiver on the River Leven (lat. $56.00812^{\circ}$, long. $-4.5886^{\circ}$ )

related to both avian and piscine predation. Goosanders, cormorants and Northern pike are relatively common in Loch Lomond (Adams 1994). Goosanders and cormorants have been reported to predate on Atlantic salmon smolts during their spring migration, and a disruption to their foraging activity increases the likelihood of salmon smolt survival (Kennedy and Greer 1988; Hawkes et al. 2013). Fourteen percent of the 49 smolts that entered Loch Lomond were categorized as being subject to avian predation and a further $4 \%$ to piscine predation (most likely pike predation). This compares with 42 and 14\%, respectively, for smolts migrating down the Endrick (Chavarie et al. submitted), thus suggesting that salmon smolts are more vulnerable to predation during riverine migration in this catchment.

Kennedy et al. (2018) analysed the movement of Atlantic salmon smolts through the Lough Erne 
catchment in the Fermanagh District, Northern Ireland. They noted that the highest rates of mortality attributed to pike predation in the river to lake confluence part of the migration route. Northern pike spawn in shallow regions with dense vegetation, habitats which are often found in river mouths (Kekäläinen et al. 2008). Northern pike may have increased in numbers in recent years due to the introduction of the invasive Gymnocephalus cernuus (Linnaeus 1758) (ruffe) (Adams 1991). We are less certain about the fate of the remaining $57 \%(n=12)$ of unsuccessful migrants. These smolts exhibited normal smolt behaviour up until a string of repeat detections occurred at a single receiver. It is unlikely that the mortality of these smolts was caused by tagging effects since size was not a predictor of migration success, and the average tag burden of smolts that migrated into Loch Lomond $(n=49)$ was $5.25 \pm 1.09 \%$, and tag burdens of up to $12 \%$ has been shown not to influence the survival of juvenile salmonids (Brown et al. 1999; Newton et al. 2016). The cessation of detections of these tags and may be attributed to movement out of the detection zone, tag loss, tag failure or predation by another aquatic predator (Klinard and Matley 2020).

No significant morphological (fork length, condition factor) factors predicted the successful migration of a smolt within and through the lake. If unsuccessful migrants experienced mortality due to predation, the relationship observed in this study does not support the central food web theory which states that a larger body size is positively correlated with body condition and predator avoidance. Both unsuccessful $(n=21$, $k=0.96 \pm 0.13)$ and successful migrants ( $n=28$; $k=0.99 \pm 0.11)$ analysed in this study had condition factors $(k)$ which are considered normal for Atlantic salmon smolts (McCormick and Björnsson 1994). This may have been due to the slight bias in the analysis introduced due to being only able to acoustically tag smolts greater than $130 \mathrm{~mm}$ and $20 \mathrm{~g}$ for tagging. Therefore, to adequately detect a size effect on predation, future studies may need to include enough small and large Atlantic salmon smolts to get a better representation of varying cohorts.

Atlantic salmon smolts in Loch Lomond appeared to migrate primarily during the night, which is thought to decrease the likelihood of being spotted by predators (Haraldstad et al. 2017; Kennedy et al. 2018). However, the benefit of this tactic was likely mitigated by their slow migration speed and apparently random migration pathways which delayed lake exit (Jepsen et al. 1998). The maximum sustained swimming speed of an Atlantic salmon smolt has been reported to be $0.50 \mathrm{~m} . \mathrm{s}^{-1}$ and is well above the estimated average minimum swimming speed observed in our study (Virtanen and Forsman 1987). Successful smolts in this study migrated at an estimated average minimum speed of $0.13 \mathrm{~m} . \mathrm{s}^{-1}$ over 5.23 days (range: 0.86-21.90; Honkanen et al. 2018, 2021; Hanssen 2020). This is consistent with a study conducted by Honkanen et al. (2021) that reported that Atlantic salmon estimated average minimum migration speed through three lakes in Scotland varied between 0.09 and $0.15 \mathrm{~m} . \mathrm{s}^{-1}$, presumably because they are not going in a straight line between receivers.

In support of our hypothesis, there was no discernible difference in the space use and migratory trajectories between successful and unsuccessful individuals. The pathways of both those fish that did migrate successfully and those that did not apparently do not differ from random movements. Unlike riverine migration, where subsequent movements occur in the direction of the river outlet, smolts in our study frequently chose pathways that deviated from progressing towards the outflowing River Leven (Thorstad et al. 2012; Urke et al. 2013; Flávio et al. 2021). For example, some smolts circled the most southern island prior to travelling towards the River Leven, while others were found to engage in long distance migrations towards the northern portion of Loch Lomond before successfully exiting the lake.

Here we used a correlated random walk model to directly test whether the migrations of Atlantic salmon smolts through Loch Lomond can be described as random. The simulated tracks of Atlantic salmon smolts fitted using a random walk model displayed varying migratory trajectories that closely resembled the trajectories of successful smolts in Loch Lomond. Simulated smolts with a $\sigma$ of $15^{\circ}$ spent up to 3.98 days in the lake travelling up to $58.54 \mathrm{~km}$, in comparison to real successful smolts which on average travelled $55.87 \mathrm{~km}$ over 5.23 days. Hanssen (2020) found that a nocturnal correlated random walk model more accurately represented the movement of Atlantic salmon smolts through Lake Evangervatnet, Norway. These results may be attributed to the fact that smolts in their study were mostly inactive during daylight hours with $91 \%$ of smolts engaging in nocturnal migration. Nocturnal migrations in Loch 
Lomond only accounted for $68 \%$ of movements, indicating that movement patterns of smolts in Loch Lomond are not wholly nocturnal. Therefore, the model assuming a realistic swim speed and turn rate migrating during the day and night may most accurately represent the movement activity of smolts in this lake (Thorpe et al., 1981; Hanssen 2020).

While the random walk model was found to closely resemble successful salmon smolt movement through Loch Lomond, the behavioural metrics used could, and should, be refined in future studies. Although there were data to draw from to characterize swim speed and step lengths of Atlantic salmon smolts, this information is not yet available for smolts migrating in standing water. To better parameterise future random walk modelling of wild smolt movement through lakes, future empirical studies should deploy a grid of receivers with overlapping detection ranges to enable more precise positional estimates using VEMCO Positioning System (VPS) or Yet Another Positioning Solver (YAPS; Baktoft et al. 2017; Guzzo et al. 2018).

While the migratory behaviour of successful smolts through Loch Lomond appears to be random, there was a distinctive difference in the behaviour of successful smolts once they came within approximately $2 \mathrm{~km}$ of the mouth of the River Leven (the outlet to Loch Lomond), the "Goldilocks zone". Contrary to our hypothesis, the Goldilocks zone was not only used by successful migrants as $56 \%$ of unsuccessful migrants $(n=5)$ entered this region. However, the Goldilocks zone was effectively defined as an important area in the lake, as once the fish entered the area, they had a high chance of migrating out of Loch Lomond, and successful migrants had a significantly higher number of movements in that area compared with outside of the zone. We may hypothesise this is because the cues available to them allow for much more directed migration into the River Leven. In rivers and estuaries, Atlantic salmon smolts have been reported to use the outflowing current to aid in migration towards the marine environment (Hedger et al. 2008; Thorstad et al. 2012; Lothian et al. 2018; Mcilvenny et al. 2021).

Thus, we conclude that, at least in this study, the survival of Atlantic salmon smolts through a standing body of water does not appear to be dependent on unique morphological or behavioural characteristics. Additionally, movement through standing waters appears to be through a series of random movements that continue until the smolts are near the lake outflow at which point the migration returns to directed movements informed by possible lake cues. While it has been reported that there is a lack of distinctive currents in large free-standing bodies of water, surface currents generated by wind may in part explain the movement patterns exhibited by smolts as smolts are known to primarily migrate within the top few metres of the water column (Svendsen et al. 2007, Mcilvenny et al. 2021). For example, Thorpe et al. (1981) noted that smolt movement in Loch Voil, Scotland, were found to swim parallel to the direction of eddies generated by wind driven surface currents. Future studies should assess whether the success of Atlantic salmon smolts in lakes is dependent upon wind-driven surface currents and currents generated at the lake outlet. This could be done through combining the known current patterns in the lake with a correlated random walk model. The River Endrick, including Loch Lomond, has been classified as a Special Area of Conservation, and Atlantic salmon is a feature of interest there being listed under Annex II in the EU habitats directive (JNCC 2019); however, numbers have been declining (Adams et al. submitted). Determining what cues are driving successful migration during a period of the life cycle typified by high mortality (this study) could help predict the response of Atlantic salmon populations to varying environmental conditions and aid in the conservation and habitat protection of smolts migrating through the River Endrick and Loch Lomond.

Acknowledgements The authors thank A. Green, A. Wright, L. Chavarie and N. McCallum for providing field support and the Loch Lomond Fisheries Trust for use of a rotary screw trap. We thank the Atlantic Salmon Trust for additional acoustic receivers and tags. Lastly, we thank two anonymous referees for their useful and thought-provoking comments and for their time taken to review this paper.

Availability of data and material The datasets used and/ or analysed during the current study are stored on the Ocean Tracking Network website (https://oceantrackingnetwork.org/) and are available from the author on reasonable request.

Code availability The $\mathrm{R}$ code used in this study is available from the author upon reasonable request.

Author contribution C.E.A designed the tagging programme, J.L, C.E.A and H.M.H executed the field work. J.L, J.M and M.N analysed the data. J.L wrote the initial manuscript 
with critical review and feedback from C.E.A, D.M.B, H.M.H, M.N and J.M.

Funding This work was part of the SeaMonitor project funded by the European Union INTERREG VA Programme award number IVA5060; additional funding was provided by the Atlantic Salmon Trust.

\section{Declarations}

Ethics approval This work was conducted under UK Home Office licence number: PP0483054.

Conflict of interest The authors declare no competing interests.

Open Access This article is licensed under a Creative Commons Attribution 4.0 International License, which permits use, sharing, adaptation, distribution and reproduction in any medium or format, as long as you give appropriate credit to the original author(s) and the source, provide a link to the Creative Commons licence, and indicate if changes were made. The images or other third party material in this article are included in the article's Creative Commons licence, unless indicated otherwise in a credit line to the material. If material is not included in the article's Creative Commons licence and your intended use is not permitted by statutory regulation or exceeds the permitted use, you will need to obtain permission directly from the copyright holder. To view a copy of this licence, visit http://creativecommons.org/licenses/by/4.0/.

\section{References}

Aarestrup K, Jepsen N, Rasmussen G, Okland F (1999) Movements of two strains of radio tagged Atlantic salmon, Salmo salar L., smolts through a reservoir. Fish Manag Ecol 6:97-107. https://doi.org/10.1046/j.1365-2400.1999. 00132.x

Adams CE (1991) Shift in pike, Esox lucius L., predation pressure following the introduction of ruffe, Gymnocephalus cernuus (L.) to Loch Lomond. J Fish Biol 38:663-667. https://doi.org/10.1111/j.1095-8649.1991.tb03155.x

Adams CE (1994) The fish community of Loch Lomond, Scotland: its history and rapidly changing status. Hydrobiologia 290:91-102. https://doi.org/10.1007/BF00008956

Agostinelli C, Lund U (2017) Circular: Circular Statistics. R Package version 0.4-93

Alerstam T, Hedenström A, Åkesson S (2003) Long-distance migration: evolution and determinants. Oikos 103:247260. https://doi.org/10.1034/j.1600-0706.2003.12559.x

Avgar T, Street G, Fryxell JM (2014) On the adaptive benefits of mammal migration. Can J Zool 92:481-490. https:// doi.org/10.1139/cjz-2013-0076

Baktoft H, Gjelland KØ, Økland F, et al. (2017). Positioning of aquatic animals based on time-of-arrival and random walk models using YAPS (Yet Another Positioning Solver) Sci Rep 7:1-10

Berry J (1933) Notes on the migration of salmon smolts from loch ness, summer 1932. Fish Scot Salmon Fish 1:1-12
Birnie-Gauvin K, Candee MM, Baktoft H et al (2018) River connectivity re-established: effects and implications of six weir removals on brown trout smolt migration. River Res Appl 34:548-554. https://doi.org/10.1002/rra.3271

Bourgeois CE, O'Connell MF (1988) Observations on the seaward migration of Atlantic salmon ( Salmo salar L.) smolts through a large lake as determined by radiotelemetry and Carlin tagging studies. Can J Zool 66:685-691. https://doi.org/10.1139/z88-101

Brown RS, Cooke SJ, Anderson WG, Mckinley RS (1999) Evidence to challenge the' $2 \%$ rule' for biotelemetry. North am J Fish Mgmt 19:867-871

Brown RS, Oldenburg EW, Seaburg AG et al (2013) Survival of seaward-migrating PIT and acoustic-tagged juvenile Chinook salmon in the Snake and Columbia Rivers: an evaluation of length-specific tagging effects. Anim Biotelem 1:8

Burnett NJ, Hinch SG, Donaldson MR, et al (2013) Alterations to dam-spill discharge influence sex-specific discharge influence sex-specific activity, behaviour, and passage success of migrating adult sockeye salmon Ecohydrol 7: 1094 - 1104. https://doi.org/10.1002/eco.1440

Calcagno V (2020) Glmulti: model selection and multimodel inference made easy. $\mathrm{R}$ package version 1.0.8

Calenge C (2006) The package adehabitat for the R software: a tool for the analysis of space and habitat use by animals. Ecol Model 197:516-519. https://doi.org/10. 1016/j.ecolmodel.2006.03.017

Campbell HA (2013) V-track: software for analysing and visualising animal movement from acoustic telemetry detections. Mar Freshw Res 63:815-820. https://doi.org/ 10.1071/MF12194

Dadswell MJ, Rulifson RA (1994) Macrotidal estuaries: a region of collision between migratory marine animals and tidal power development. Biol J Linnean Soc 51:93-113

Davidsen JG, Rikardsen AH, Halttunen E et al (2009) Migratory behaviour and survival rates of wild northern Atlantic salmon Salmo salar post-smolts: effects of environmental factors. J Fish Biol 75:1700-1718. https://doi.org/10.1111/j.1095-8649.2009.02423.x

De Clippele LH, Risch D (2021) Measuring sound at a coldwater coral reef to assess the impact of COVID-19 on noise pollution. Front Mar Sci 8:674702. https://doi.org/ 10.3389/fmars.2021.674702

Duffing Romero MD, Matley JK, Luo J, et al (2021) Movement patterns of juvenile Atlantic tarpon (Megalops atlanticus) in Brewers Bay, St. Thomas, U.S. Virgin Islands. Anim biotelemetry 9:16. https://doi.org/10.1186/ s40317-021-00239-x

Espinoza M, Lédée EJI, Simpfendorfer CA et al (2015) Contrasting movements and connectivity of reef-associated sharks using acoustic telemetry: implications for management. Ecol Appl 25:2101-2118. https://doi.org/10.1890/ $14-2293.1$

Flávio H, Caballero P, Jepsen N, Aarestrup K (2021) Atlantic salmon living on the edge: smolt behaviour and survival during seaward migration in river Minho. Ecol Freshw Fish 30:61-72. https://doi.org/10.1111/eff.12564

Goossens J, T'Jampens M, Deneudt K, Reubens J (2020) Mooring scientific instruments on the seabed-design, 
deployment protocol and performance of a recoverable frame for acoustic receivers. Methods Ecol Evol 11:974979. https://doi.org/10.1111/2041-210X.13404

Guzzo MM, Blanchfield PJ, Chapelsky AJ, Cott PA (2016) Resource partitioning among top-level piscivores in a subArctic lake during thermal stratification. J Great Lakes Res 42:276-285. https://doi.org/10.1016/j.jglr.2015.05.014

Guzzo MM, Van Leeuwen TE, Hollins J et al (2018) Field testing a novel high residence positioning system for monitoring the fine-scale movements of aquatic organisms. Methods Ecol Evol 9:1478-1488. https://doi.org/10.1111/ 2041-210X.12993

Hanssen EM (2020) Novel telemetry predation sensors and mechanistic models reveal the tribulations of Atlantic salmon (Salmo salar) smolts migrating through lakes. Masters Thesis, University of Bergen

Haraldstad T, Kroglund F, Kristensen T, Jonsson B, Haugen TO (2017) Diel migration patterns of Atlantic salmon (Salmo salar) and sea trout (Salmo trutta) smolts: an assessment of environmental cues. Ecol Freshw Fish 26:541-551. https://doi.org/10.1111/eff.12298

Harris A (2012) astroFns: astronomy: time and position functions, misc. utilities. $\mathrm{R}$ package version 4.1-0

Hawkes JP, Saunders R, Vashon AD, Cooperman MS (2013) Assessing efficacy of non-lethal harassment of doublecrested cormorants to improve Atlantic Salmon smolt survival. Northeast Nat 20:1-18. https://doi.org/10. 1656/045.020.0101

Hayden TA, Holbrook CM, Binder TR et al (2016) Probability of acoustic transmitter detections by receiver lines in Lake Huron: results of multi-year field tests and simulations. Anim Biotelemetry 4:19. https://doi.org/10.1186/ s40317-016-0112-9

Hedger R, Martin F, Hatin D et al (2008) Active migration of wild Atlantic salmon Salmo salar smolt through a coastal embayment. Mar Ecol Prog Ser 355:235-246. https://doi.org/10.3354/meps07239

Holbrook C, Hayden T, Pye J, Nunes A (2018) Glatos: a package for the Great Lakes acoustic telemetry observation system. $\mathrm{R}$ package version 0.4 .2

Honkanen HM, Orrell DL, Newton M et al (2021) The downstream migration success of Atlantic salmon (Salmo salar) smolts through natural and impounded standing waters. Ecol Eng 161:106161. https://doi.org/10.1016/j. ecoleng.2021.106161

Honkanen HM, Rodger JR, Stephen A et al (2018) Counterintuitive migration patterns by Atlantic salmon Salmo salar smolts in a large lake. J Fish Biol 93:159-162. https://doi.org/10.1111/jfb. 13650

Horton TW, Block BA, Drumm A et al (2020) Tracking Atlantic bluefin tuna from foraging grounds off the west coast of Ireland. ICES J Mar Sci 77:2066-2077. https:// doi.org/10.1093/icesjms/fsaa090

Hunt G, Renner M, Kuletz K et al (2018) Timing of seaice retreat affects the distribution of seabirds and their prey in the southeastern Bering Sea. Mar Ecol Prog Ser 593:209-230. https://doi.org/10.3354/meps 12383

Hussey NE, Kessel ST, Aarestrup K et al (2015) Aquatic animal telemetry: a panoramic window into the underwater world. Science 348:1255642. https://doi.org/10.1126/ science. 1255642
Jepsen N, Aarestrup K, Økland F, Rasmussen G (1998) Survival of radio-tagged Atlantic salmon (Salmo salar L.) and trout (Salmo trutta L.) smolts passing a reservoir during seaward migration. Hydrobiologia 372:347-353

Kekäläinen J, Niva T, Huuskonen H (2008) Pike predation on hatchery-reared Atlantic salmon smolts in a northern Baltic river. Ecol Freshw Fish 17:100-109. https://doi. org/10.1111/j.1600-0633.2007.00263.x

Kennedy BM, Gale WL, Ostrand KG (2007) Relationship between smolt gill $\mathrm{Na}+\mathrm{K}+$ ATPase activity and migration timing to avian predation risk of steelhead trout (Oncorhynchus mykiss) in a large estuary. Can J Fish Aquat Sci 64:1506-1516

Kennedy GJA, Greer JE (1988) Predation by cormorants, Phalacrocorax carbo (L.), on the salmonid populations. Aquac Fish Manag 19:159-170

Kennedy RJ, Rosell R, Millane M et al (2018) Migration and survival of Atlantic salmon Salmo salar smolts in a large natural lake. J Fish Biol 93:134-137. https://doi.org/10. 1111/jfb. 13676

Klemetsen A, Amundsen P-A, Dempson JB et al (2003) Atlantic salmon Salmo salar L., brown trout Salmo trutta L. and Arctic charr Salvelinus alpinus (L.): a review of aspects of their life histories. Ecology Freshwater Fish 12:1-59. https://doi.org/10.1034/j.1600-0633.2003.00010.x

Klinard, NV, Matley JK (2020) Living until proven dead: addressing mortality in acoustic telemetry research. Rev Fish Biol 30:485-499. 9. https://doi.org/10.1007/ s11160-11020-09613-z

Lacroix GL, Knox D, McCurdy P (2004a) Effects of implanted dummy acoustic transmitters on juvenile Atlantic Salmon. Trans Am Fish Soc 133:211-220

Lacroix GL, McCurdy P, Knox D (2004b) Migration of Atlantic Salmon postsmolts in relation to habitat use in a coastal system. Trans Am Fish Soc 133:1455-1471. https://doi. org/10.1577/T03-032.1

Lennox RJ, Pulg U, Malley B et al (2021) The various ways that anadromous salmonids use lake habitats to complete their life history. Can J Fish Aquat Sci 78:90-100. https:// doi.org/10.1139/cjfas-2020-0225

Limburg KE, Waldman JR (2009) Dramatic declines in North Atlantic diadromous fishes. BioScience 59:955-965. https://doi.org/10.1525/bio.2009.59.11.7

Lothian AJ, Newton M, Barry J et al (2018) Migration pathways, speed, and mortality of Atlantic salmon (Salmo salar) smolts in a Scottish river and the near-shore coastal marine environment. Ecol Freshw Fish 27:549-558. https://doi.org/10.1111/eff.12369

Lund U, Agostinelli C (2018) CircStats: Circular Statistics, from "Topics in Circular Statistics." R Package version 0.2-6

Maitland PS, Adams CE, Mitchell J (2000) The natural heritage of Loch Lomond: its importance in a national and international context. Scott Geogr J 1 116:181-196. https://doi.org/10.1080/00369220018737093

McCormick SD, Björnsson BT (1994) Physiological and hormonal differences among Atlantic salmon parr and smolts reared in the wild, and hatchery smolts. Aquaculture 121:235-244. https://doi.org/10.1016/0044-8486(94) 90023-X

McCormick SD, Naiman RJ, Montgomery ET (1985) Physiological smolt characteristics of anadromous and 
non-anadromous brook trout (Salvelinus fontinalis) and Atlantic Salmon (salmo Salar). Can J Fish Aquat Sci 42:529-538

Mcilvenny J, Youngson A, Williamson BJ, et al (2021) Combining acoustic tracking and hydrodynamic modelling to study migratory behaviour of Atlantic salmon (Salmo salar) smolts on entry into high-energy coastal waters. ICES J mar Sci fsab111. https://doi.org/10.1093/icesjms/ fsab111

Mueller T, Fagan WF (2008) Search and navigation in dynamic environments - from individual behaviors to population distributions. Oikos 117:654-664. https://doi.org/10. 1111/j.0030-1299.2008.16291.x

Murray J, Pullar L (1910) Bathymetric survey of the freshwater lochs of Scotland. P. Challenger Office, Edinburgh

Newton M, Barry J, Dodd JA et al (2016) Does size matter? A test of size-specific mortality in Atlantic salmon Salmo salar smolts tagged with acoustic transmitters. J Fish Biol 89:1641-1650. https://doi.org/10.1111/jfb.13066

Nunn AD, Cowx IG (2012) Restoring river connectivity: prioritizing passage improvements for diadromous fishes and lampreys. AMBIO 41:402-409. https://doi.org/10.1007/ s13280-012-0281-6

Pedersen L-F, Koed A, Malte H (2008) Swimming performance of wild and F1-hatchery-reared Atlantic salmon (Salmo salar) and brown trout (Salmo trutta) smolts. Ecol Freshw Fish 17:425-431. https://doi.org/10.1111/j.16000633.2008.00293.x

Pincock DG (2012) False detections: what they are and how to remove them from detection data. VEMCO, Halifax

Puijenbroek PJTM, Buijse AD, Kraak MHS, Verdonschot PFM (2019) Species and river specific effects of river fragmentation on European anadromous fish species. River Res Applic 35:68-77. https://doi.org/10.1002/rra.3386

Reubens J, Verhelst P, van der Knaap I et al (2019) Environmental factors influence the detection probability in acoustic telemetry in a marine environment: results from a new setup. Hydrobiologia 845:81-94. https://doi.org/10. 1007/s10750-017-3478-7

SEPA (2021). SEPA water level data. https://www2.sepa.org. uk/waterlevels/default.aspx?sd=t\&lc $=133086$. Accessed 16 August 2021

Simpfendorfer CA, Heupel MR, Hueter RE (2002) Estimation of short-term centers of activity from an array of omnidirectional hydrophones and its use in studying animal movements. Can J Fish Aquat Sci 59:23-32. https://doi. org/10.1139/f01-191

Smith IR, Lyle AA (1979) Distribution of fresh waters in Great Britain. Institute of Terrestrial Ecology, Cambridge

Svendsen JC, Eskesen AO, Aarestrup K et al (2007) Evidence for non-random spatial positioning of migrating smolts (Salmonidae) in a small lowland stream. Freshw Biol 52:1147-1158. https://doi.org/10.1111/j.1365-2427.2007. 01743.x

Tamario C, Sunde J, Petersson E et al (2019) Ecological and evolutionary consequences of environmental change and management actions for migrating fish. Front Ecol Evol 7:271. https://doi.org/10.3389/fevo.2019.00271

Thieurmel B, Elmarhraoui A (2019) Suncalc: compute sun position, sunlight phases, moon position, and lunar phase. $\mathrm{R}$ package version 0.5 .0
Thorne A, MacDonald AI, Thorley JL (2016) The abundance of large, piscivorous Ferox trout (Salmo trutta) in loch Rannoch, Scotland. PeerJ 4:e2646

Thorpe JE (1977) Daily ration of adult perch Perca fluviatilis L. during summer in loch Leven, Scotland. J Fish Biol 11:55-68

Thorpe JE, Ross LG, Struthers G, Watts W (1981) Tracking Atlantic salmon smolts, Salmo salar L., through loch Voil, Scotland. J Fish Biology 19:519-537. https://doi.org/10. 1111/j.1095-8649.1981.tb03820.x

Thorstad E, kland F, Finstad B, et al (2004) Migration speeds and orientation of Atlantic salmon and sea trout postsmolts in a Norwegian fjord system. Environ Biol Fish 71:305-311. https://doi.org/10.1007/s10641-004-1264-7

Thorstad EB, Whoriskey F, Uglem I et al (2012) A critical life stage of the Atlantic salmon Salmo salar: behaviour and survival during the smolt and initial post-smolt migration. J Fish Biol 81:500-542. https://doi.org/10.1111/j.10958649.2012.03370.x

Thorstad EB, Whoriskey FG, Rikardsen AH, Aarestrup K (2011) Aquatic nomads: the life and migrations of the Atlantic salmon. In: Aas $\varnothing$, Einum S, Klemesten A, Skurdal J (eds) Atlantic Salmon ecology. Wiley-Blackwell, Oxford, pp 1-32

Thurstan RH, Roberts CM (2010) Ecological meltdown in the firth of Clyde, Scotland: two centuries of change in a coastal marine ecosystem. PLoS One 5:e11767. https:// doi.org/10.1371/journal.pone.0011767

Tucker S, Mark Hipfner J, Trudel M (2016) Size- and condition-dependent predation: a seabird disproportionately targets substandard individual juvenile salmon. Ecology 97:461-471. https://doi.org/10.1890/15-0564.1

Udyawer V, Dwyer RG, Hoenner X et al (2018) A standardised framework for analysing animal detections from automated tracking arrays. Anim Biotelemetry 6:17. https:// doi.org/10.1186/s40317-018-0162-2

Urke HA, Kristensen T, Ulvund JB, Alfredsen JA (2013) Riverine and fjord migration of wild and hatchery-reared Atlantic salmon smolts. Fish Manag Ecol 20:544-552. https://doi.org/10.1111/fme.12042

Virtanen E, Forsman L (1987) Physiological responses to continuous swimming in wild salmon (Salmo salar L.) parr and smolt. Fish Physiol Biochem 4:157-163. https://doi. org/10.1007/BF02110882

Vogel E, Biuw M, Blanchet M et al (2021) Killer whale movements on the Norwegian shelf are associated with herring density. Mar Ecol Prog Ser 665:217-231. https://doi.org/ 10.3354/meps 13685

Weinz AA, Matley JK, Klinard NV et al (2020) Identification of predation events in wild fish using novel acoustic transmitters. Anim Biotelemetry 8:28. https://doi.org/10.1186/ s40317-020-00215-x

Zydlewski GB, Stich DS, McCormick SD (2014) Photoperiod control of downstream movements of Atlantic salmon Salmo salar smolts: photoperiod and smolt downstream movement. J Fish Biol 85:1023-1041. https://doi.org/10. 1111/jfb.12509

Publisher's note Springer Nature remains neutral with regard to jurisdictional claims in published maps and institutional affiliations. 